\title{
PENGGUNAAN MODIFIKASI PERMAINAN BOLAVOLI UNTUK MENINGKATKAN KEMAMPUAN PASSING BAWAH
}

\author{
Fauzan Effendy ${ }^{1}$, Yudhi Kharisma ${ }^{2}$, Riki Ramadhan ${ }^{3}$ \\ 1, 2, ${ }^{3}$ Program Studi Pendidikan Jasmani Kesehatan dan Rekreasi, \\ STKIP Nahdlatul Ulama Indramayu, Jln. Raya Kaplongan No. 28 Indramayu, Jawa Barat \\ 1e-mail: Fauzan_effendy@stkipnu.ac.id
}

\begin{abstract}
Abstrak
Penelitian ini bertujuan sebagai upaya meningkatkan kemampuan passing bawah melalui media modifikasi permainan 3 on 3 untuk permainan bolavoli. Penelitian ini merupakan penelitian tindakan kelas dengan model Kemmis dan McTaggart. Subyek penelitian yang digunakan adalah peserta didik kelas X yang berjumlah 25 peserta didik di SMA NU Kaplongan Indramayu. Teknik pengumpulan data menggunakan tes passing bawah bolavoli. Teknik analisis data dilakukan secara deskriptif kuantitatif yang mengacu pada Penilaian Acuan Patokan (PAP) dan mengambil persentase tingkat ketuntasan belajar peserta didik. Pada prasiklus persentase tingkat ketuntasan sebesar 36\% dengan nilai rata-rata kelas sebesar 68.6, pada siklus 1 tingkat ketuntasan sebesar 56\% dengan nilai rata-rata kelas sebesar 76.4, serta siklus 2 menunjukkan tingkat ketuntasan sebesar $86 \%$ dengan nilai ratarata kelas sebesar 82.2. Hasil diatas menunjukkan bahwa terjadi peningkatan ketuntasan belajar pada materi passing bawah dengan menggunakan media modifikasi permainan 3 on 3 sejak pelaksanaan prasiklus sampai pada tahap siklus 2 sebesar $50 \%$.
\end{abstract}

Kata kunci: passing bawah, bolavoli, modifikasi permainan

\begin{abstract}
This study aims as an effort to improve the capabilities of under-pass that used media modification game 3 on 3 for volleyball games. This research is a classroom action research model by Kemmis and McTaggart. The research subjects used were class $X$ students who numbered 25 students at NU Kaplongan Indramayu High School. Technique data collection that used in this study was to use a volleyball under-pass test. The data analysis technique was carried out in a quantitative descriptive manner which refers to the Reference Benchmarking (PAP) and take a percentage of the level of mastery learning of students. In the pre-cycle percentage of completeness level of $36 \%$ with an average grade of 68.6, in cycle 1 the level of completeness is increased to 56\% with an average grade of 76.4, and cycle 2 shows an inreased again on level of completeness of $86 \%$ with an average grade of 82.2. The results above indicate that there is an increase in mastery learning under the passing material using a 3 on 3 game modification media since the implementation of pre-cycle until the second cycle stage with 50\% percentage increased.
\end{abstract}

Keywords: under-pass, volleyball, game modification

\section{PENDAHULUAN}

Olahraga dalam konteks pendidikan memiliki definisi sebagai sarana untuk mendidik peserta didik melalui proses gerak. Sistem perundang-undangan negara menyatakan bahwa pendidikan adalah usaha sadar dan terencana untuk 
mewujudkan suasana belajar dan prosses pembelajaran agar peserta didik secara aktif dapat mengembangkan potensinya guna memiliki kekuatan spiritual, kecerdasan emosional, dan keterampilan yang diperlukan baik untuk pribadi, bangsa, dan negara (Hanansyah dan Ginanjar, 2019: 91). Sasaran dari pendidikan jasmani adalah; (1) memberikan pengalaman pendidikan melalui gerak agar kemampuan motorik peserta didik selaras dengan proses tumbuh kembang, (2) sebagai tempat untuk mengembangkan segala potensi yang dimiliki peserta didik sesuai dengan cita-cita pendidikan secara keseluruhan termasuk untuk aspek kognitif dan afektif peserta didik (Fajri, 2019: 65).

Seiring dengan semakin pesatnya kemajuan IPTEKS khususnya di Indonesia yang secara tidak langsung berimbas pada turunnya minat belajar peserta didik disekolah, karena di era tanpa keterbatasan akses informasi ini peserta didik saat ini khususnya di lingkup SMA yang rata-rata sudah dibekali oleh perangkat teknologi (ex. Smartphone) oleh orang tuanya bisa mendapatkan lebih banyak pengetahuan serta keterampilan melalui internet. Hal ini seharusnya menjadi PR bagi para pengajar bagaimana untuk bisa meningkatkan kembali minat belajar peserta didik disekolah yang telah ter-"distract" oleh hal tersebut diatas. Mata pelajaran PJOK dapat dijadikan sebagai solusi yang tepat untuk mengentaskan problematika tersedut diatas. Karena, materi yang diajarkankan hampir seluruhnya lewat gerak, dengan gerak sanggup membuat peserta didik untuk sementara lepas dari perangkat teknologi (Subekti, Hanief, dan Mashuri, 2018: 162). Masalah tidak berhenti sampai disini, karena Pengajar PJOK pun terkadang dalam pemberian materi pelajaran terlalu monoton dan terfokus pada beberapa peserta didik saja dan tidak menyeluruh, hal ini berakibat pada adanya sebagian peserta didik yang tidak berpartisipasi aktif selama proses pembelajaran berlangsung. Hal ini tidak selaras dengan pengertian bahwa pendidikan jasmani merupakan proses pendidikan yang memanfaatkan aktivitas jasmani yang direncanakan secara sistematik, bertujuan untuk meningkatkan individu secara organik, neuromuscular, perseptual, kognitif, sosial dan emosional. (Depdiknas, 2003) serta pendapat yang menyatakan bahwa tujuan ideal program pendidikan 
jasmani bersifat menyeluruh, sebab mencakup bukan hanya aspek fisik tetapi juga aspek lainnya yang mencakup aspek intelektual, emosional, sosial dan moral dengan maksud kelak anak muda itu menjadi seseorang yang percaya diri, berdisiplin, sehat, bugar dan hidup bahagia (Lutan, 2001). Oleh karena itu, pengajar dituntut untuk mampu mengembangkan pembelajaran yang efektif, disamping harus memahami dan memperhatikan karakteristik dan kebutuhan peserta didik (Arifin, 2017: 21). Untuk itu diperlukan suatu pendekatan pembelajaran yang tepat untuk bisa memecahkan masalah tersebut.

Pendekatan pembelajaran PJOK menggunakan modifikasi permainan merupakan satu dari sekian banyak upaya yang bisa dilaksanakan oleh para pengajar supaya proses pembelajaran mampu mencerminkan asas DAP (Developmentally Appropriate Practice). Artinya bahwa tugas ajar yang disampaikan harus memperhatikan perubahan kemampuan dan kondisi peserta didik, serta sanggup membantu mendorong ke arah perubahan tersebut. Esensi memodifikasi tersebut adalah untuk menganalisa serta mengembangkan materi pelajaran dengan cara meruntunkannya dalam bentuk aktivitas belajar yang potensial sehingga dapat memperlancar peserta didik dalam dalam proses belajar (Saputra, 2015: 36). Sehingga mampu menciptakan pembelajaran yang berkualitas menurut Hidayatullah (2010) pembelajaran yang berkualitas, setidaknya memiliki beberapa indikator, yaitu: (1) menantang; menyenangkan; (3) mendorong eksplorasi; (4) memberi pengalaman sukses; dan (5) mengembangkan kecakapan berfikir. Modifikasi dalam mata pelajaran pendidikan jasmani diperlukan, dengan tujuan agar peserta didik memperoleh kepuasan dalam mengikuti pelajaran, meningkatkan kemungkinan keberhasilan dalam berpartisipasi dan dapat melakukan pola gerak secara benar (Lutan, 1988). Pendekatan ini memiliki maksud agar materi pembelajaran dapat disajikan sesuai dengan tahapan kognitif, afektif, dan psikomotor peserta didik. Sehingga tujuan dari pembelajaran bisa dicapai. Modifikasi digunakan sebagai salah satu alternatif pendekatan dalam pembelajaran pendidikan jasmani yang dilakukan dengan berbagai pertimbangan (Bahagia, 2014: 30). Ngasmain dan Soepartono 
(1997) mengemukakan alasan diperlukannya modifikasi dalam pembelajaran adalah: (1) Anak bukanlah orang dewasa dalam bentuk kecil, kematangan fisik dan metal anak belum selengkap orang dewasa; (2) pendekatan pembelajaran pendidikan jasmani selama ini kurang efektif, hanya bersifat lateral dan monoton; dan (3) sarana dan prasarana pembelajaran pendidikan jasmani yang ada sekarang hampir seluruhnya didesain untuk orang dewasa. Sementara itu Aussie (1996) mengembangkan modifikasi di Australia dengan pertimbangan sebagai berikut: (1) Anak-anak belum memiliki kematangan fisik dan emosional seperti orang dewasa, (2) berolahraga dengan peralatan dan peraturan yang dimodifikasi akan mengurangi resiko cedera pada anak, (3) Olahraga yang dimodifikasi akan mampu mengembangkan keterampilan anak lebih cepat dibandingkan dengan peralatan standar untuk orang dewasa, (4) Olahraga yang dimodifikasi menumbuhkan kegembiraan dan kesenangan pada anak-anak dala situasi kompetitif. Beberapa komponen yang dapat dimodidikasi sebagai pendekatan dalam pembelajaran PJOK diantaranya, sebagai berikut (Aussie, 1996): (1) Ukuran, berat atau bentuk peralatan yang digunakan, (2) lapangan permainan, (3) waktu bermain/lamanya permainan, (4) peraturan permainan, dan (5) jumlah pemain.

Dalam struktur kurikulum PJOK di SMA, salah satu materi yang bisa dimodifikasi adalah bolavoli. Dalam kerangka kurikulum PJOK, bolavoli juga masuk dalam kategori materi pokok permainan bola besar. Untuk bisa memainkan permainan bolavoli ini minimal ada dua teknik dasar yang sangat fundamental untuk dikuasai yaitu, servis dan passing. Teknik dasar yang lainnya dalam permainan bolavoli adalah smash dan block. Permainan bolavoli merupakan salah satu olahraga populer di Indonesia, selain badminton dan sepakbola. Namun dalam konteks pembelajaran di SMA, seringkali dijumpai saat materi permainan diajarkan yang berpartisipasi aktif hanya peserta didik tertentu. Pengajar juga seringkali memberikan materi permainan beregu seperti bolavoli ini dengan langsung pada real game. Sehingga peserta didik yang memang "awam" dalam permainan ini akan duduk diam menyaksikan peserta didik yang lain bermain. Hal ini sesuai dengan 
pernyataan Roberts dan Fairclough bahwa pendidikan jasmani yang terpusat pada model pengajaran langsung menghasilkan tingkat ketidakaktifan peserta didik yang tinggi (Ginanjar, Suherman, Juliantine, dan Hidayat, 2019; Hanansyah dan Ginanjar, 2019). Hal ini jika dibiarkan oleh pengajar akan berdampak pada lemahnya penguasaan keterampilan peserta didik dalam permainan bolavoli khususnya keterampilan passing bawah. Pernyataan-pernyataan diatas seakan didukung dengan data hasil pra-siklus yang telah dilaksanakan di SMA NU Kaplongan Indramayu, dengan melakukan wawancara dan diskusi dengan salah satu pengajar PJOK disana, diperoleh informasi bahwa di SMA minat peserta didik dalam mengikuti pelajaran PJOK masih kurang, sebagian besar peserta didik kurang berpartisipasi saat pembelajaran berlangsung khususnya pada materi pembelajaran passing bawah bolavoli. Tidak mengherankan jika nilai pada materi passing bawah bolavoli peserta didik SMA NU Kaplongan Indramayu masih rendah dan masih banyak yang belum dapat memenuhi standar Kriteria Kelulusan Minimal (KKM) yang telah ditentukan di sekolah tersebut yaitu sebesar 75, dimana dari 25 peserta didik khususnya kelas $\mathrm{X}$ hanya 2 peserta didik yang memenuhi nilai standar KKM untuk materi passing bawah. Banyak faktor yang menjadi penyebab lemahnya output hasil pembelajaran passing bawah, diantaranya adalah minat peserta didik dalam mengikuti pelajaran PJOK sehingga selama pembelajaran berlangsung, peserta didik jadi kurang berpartisipasi aktif, yang pada akhirnya akan berimbas terhadap nilai peserta didik yang rendah. Kemudian, ada faktor internal pada peserta didik itu sendiri, yang merasa jenuh dengan strategi pemberian materi yang monoton dan begitu-begitu saja oleh pengajar, yang terbiasa memberikan materi pokok tanpa disertai permainan atau variasi pembelajaran yang menarik yang dapat menggugah partisipasi aktif dari peserta didik selama mengikuti pembelajaran PJOK. Sehingga perlu diberikan materi pembelajaran yang bervariasi yang dikemas secara menarik dan sesuai dengan karakteristik peserta didik dilingkungan SMA.

Oleh karena itu, perlu disusun suatu media modifikasi pembelajaran khususnya untuk permainan bolavoli materi passing bawah. Sebuah modifikasi 
permainan bolavoli yang menyenangkan sehingga peserta didik bisa bermain sekaligus belajar, serta diharapkan mampu mengatasi permasalahan yang sudah dibahas diatas. Modifikasi permainan yang dimaksud adalah permainan 3 on 3 . Permainan 3 on 3 merupakan permainan bolavoli yang dimodifikasi sedemikian rupa dari jumlah pemain, ukuran lapangan dan tinggi net dengan tujuan untuk meningkatkan kemampuan peserta didik dalam melakukan passing bawah bolavoli (Indriyani, 2011). Dimana dengan adanya modifikasi permainan ini selain bertujuan untuk meningkatkan partisipasi aktif peserta didik selama mengikuti materi pembelajaran passing bawah bolavoli disekolah, yang pada akhirnya diharapkan dapat meningkatkan keterampilan peserta didik melakukan passing bawah bolavoli. Pembelajaran yang dirancang dalam bentuk permainan bertujuan untuk memenuhi hasrat gerak yang di dalamnya terdapat unsur belajar. Penggunaan modifikasi permainan dalam pembelajaran dapat menciptakan proses belajar mengajar yang menyenangkan dan tercapainya tujuan dari pembelajaran tersebut.

\section{METODE}

Penelitian ini adalah penelitian tindakan kelas dengan menggunakan model Kemmis dan McTaggart yang prosedurnya mencakup, perencanaan, pelaksanaan \& observasi, dan refleksi atau biasa dikenal dengan siklus. Subjek penelitian ini adalah peserta didik yang duduk di bangku kelas $\mathrm{X}$ di SMA NU Kaplongan Indramayu yang berjumlah 25 peserta didik. Prosedur awal yang dilaksanakan dalam penelitian dimulai dengan observasi terhadap peserta didik kelas $\mathrm{X}$ di lingkungan SMA NU Kaplongan Indramayu selama proses pembelajaran permainan bolavoli dengan materi passing bawah. Data hasil observasi tersebut mengindikasikan terdapat masalah, maka untuk memberi solusi terhadap masalah tersebut dengan menggunakan modifikasi permainan 3 on 3 untuk peserta didik di SMA. (1) Perencanaan, dalam langkah ini tahap yang dipakai meliputi pembuatan skenario pembelajaran menggunakan media modifikasi permainan 3 on 3 untuk materi passing bawah. Kemudian, membuat tes passing bawah yang dipergunakan 
sebagai indikator keberhasilan proses belajar; (2) pelaksanaan tindakan, melaksanakan pembelajaran yang sudah di skenario secara obyektif, sistematis, kritis, dan sadar melalui modifikasi permainan 3 on 3; (3) observasi, selama proses pembelajaran berlangsung peneliti mengobservasi subyek yang diteliti sebagai pelaksana penelitian; (4) analisis dan refleksi, data hasil yang diperleh selama menggunakan media modifikasi permainan 3 on 3 dianalisa serta direfleksikan bahwa dengan media modifikasi permainan tersebut berefek positif terhadap hasil belajar peserta didik pada materi passing bawah.

Instrumen Pengumpulan data menggunakan tes passing bawah 60 detik untuk peserta didik berusia 15-17 tahun yang dilaksanakan pada akhir permainan di setiap siklus pengajar mengambil nilai keterampilan passing bawah menggunakan tes passing bawah dimana peserta didik melakukan passing bawah secara individu selama 60 detik, yang bertujuan untuk mengetahui berapa kali bola dapat di passing dalam waktu tersebut.. Passing bawah yang dianggap benar dihitung adalah bila bola mencapai ketinggian bola minimal 2, 30 meter untuk putra dan 2, 15 meter untuk putri dan dilakukan dalam area dalam 60 detik (Depdiknas, 1999). Untuk perhitungan tes dilakukan dengan melihat PAP (Patokan Acuan Penilaian) pada Tabel 1.

Analisis data hasil belajar peserta didik dilakukan dengan mengambil nilai teknik passing bawah yang sudah dilakukan sebelumnya dengan melakukan perhitungan nilai tes keterampilan dengan melihat Patokan Acuan Penilaian (PAP), yang kemudian dianalisa dengan menggunakan deskriptif statistik yang mengacu pada besaran nilai KKM peserta didik dan kelas pada mata pelajaran PJOK, dinyatakan tuntas apabila nilai peserta didik dan rata-rata kelas mencapai nilai KKM sebesar 75. Berikut adalah instrumen Penilaian Acuan Patokan (PAP) yang dipakai untuk menilai keterampilan passing bawah bagi peserta didik setelah melaksanakan tes keterampilan passing bawah. 
p-ISSN: 2089-2829

e-ISSN: 2407-1528

http://journal.ikippgriptk.ac.id/index.php/olahraga

DOI: 10.31571/jpo.v9i1.1333
Jurnal Pendidikan Olahraga

Vol.9, No.1 Juni 2020

hal $1-14$

Tabel 1 Patokan Acuan Penilaian

\begin{tabular}{|c|c|c|}
\hline $\begin{array}{l}\text { Persentase } \\
\text { Ketuntasan }\end{array}$ & $\begin{array}{c}\text { Perolehan } \\
\text { Skor Tes } \\
\text { Passing }\end{array}$ & $\begin{array}{c}\text { Nilai Akhir } \\
\text { Passing } \\
\text { Bawah }\end{array}$ \\
\hline $100 \%$ & $>45$ & 100 \\
\hline $95 \%$ & 43 & 95 \\
\hline $90 \%$ & 41 & 90 \\
\hline $85 \%$ & 38 & 85 \\
\hline $80 \%$ & 36 & 80 \\
\hline $75 \%$ & 34 & 75 \\
\hline $70 \%$ & 32 & 70 \\
\hline $65 \%$ & 29 & 65 \\
\hline $60 \%$ & 27 & 60 \\
\hline $55 \%$ & 25 & 55 \\
\hline $50 \%$ & 23 & 50 \\
\hline $45 \%$ & 20 & 45 \\
\hline $40 \%$ & 18 & 40 \\
\hline $35 \%$ & 16 & 35 \\
\hline $30 \%$ & 14 & 30 \\
\hline $25 \%$ & 11 & 25 \\
\hline $20 \%$ & 9 & 20 \\
\hline $15 \%$ & 7 & 15 \\
\hline $10 \%$ & 4 & 10 \\
\hline $5 \%$ & 2 & 5 \\
\hline $0 \%$ & 0 & 0 \\
\hline
\end{tabular}

\section{HASIL DAN PEMBAHASAN}

Berdasarkan hasil saat pelaksanaan prasiklus yang dilaksanakan pada peserta didik kelas X di SMA NU Kaplongan saat pembelajaran bolavoli materi passing bawah persentase tingkat ketuntasan belajar mencapai 36\% dengan ratarata nilai sebesar 68,6 dari 25 peserta didik dengan hanya 9 peserta didik yang 
mencapai KKM (Tabel 2 dan Gambar 1). Dikarenakan saat prasiklus banyak peserta didik yang belum tuntas, maka dilanjutkan pada tahap siklus 1. Pada siklus $1 \mathrm{KKM}$ peserta didik meningkat dengan persentase tingkat ketuntasan mencapai $56 \%$, disertai dengan meningkatnya nilai rata-rata kelas yang mencapai angka 76,4 dengan rincian 14 peserta didik yang mencapai KKM, dan 11 peserta didik yang belum mencapai KKM. Dari rata-rata nilai siklus 1 KKM kelas sudah tercapai karena sudah melewati angka 75 yang sudah ditetapkan (Tabel 2 dan Gambar 2).

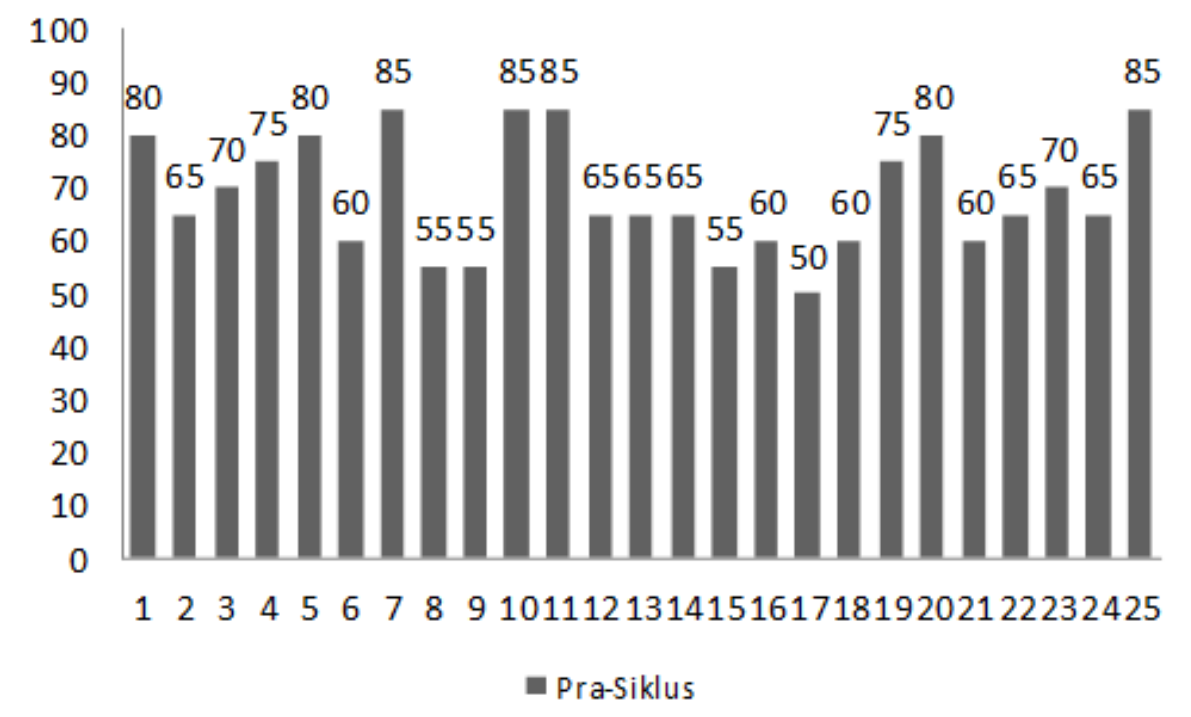

Gambar 1 Perolehan Nilai Peserta Didik Saat Pra-Siklus

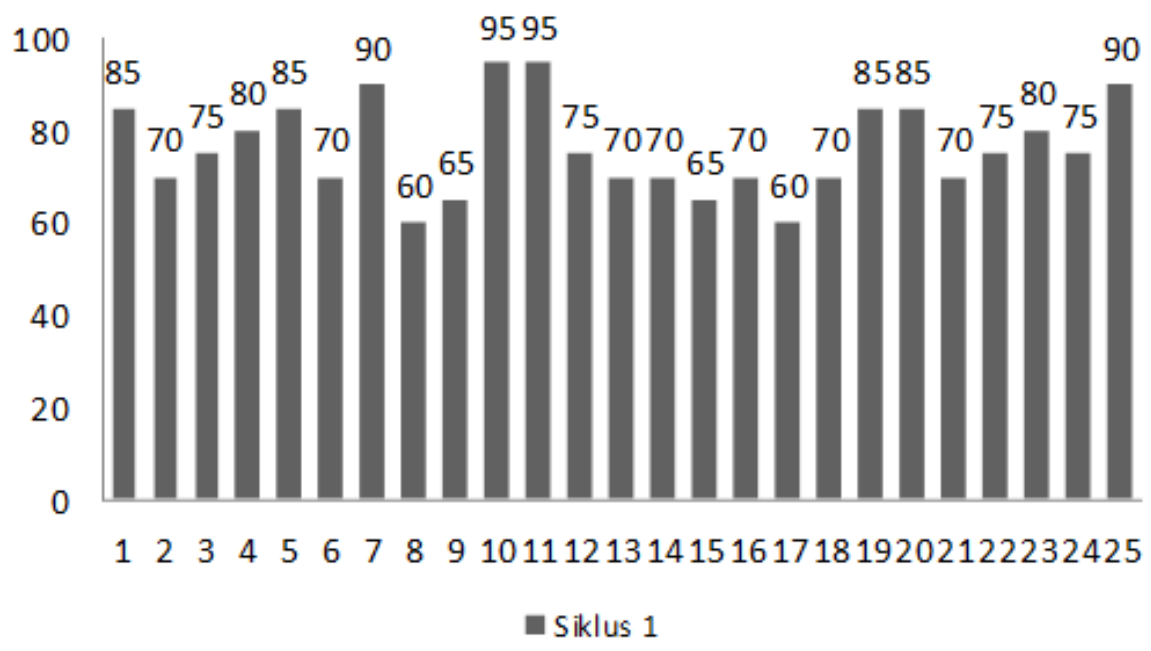

Gambar 2 Perolehan Nilai Peserta Didik Saat Siklus 1 


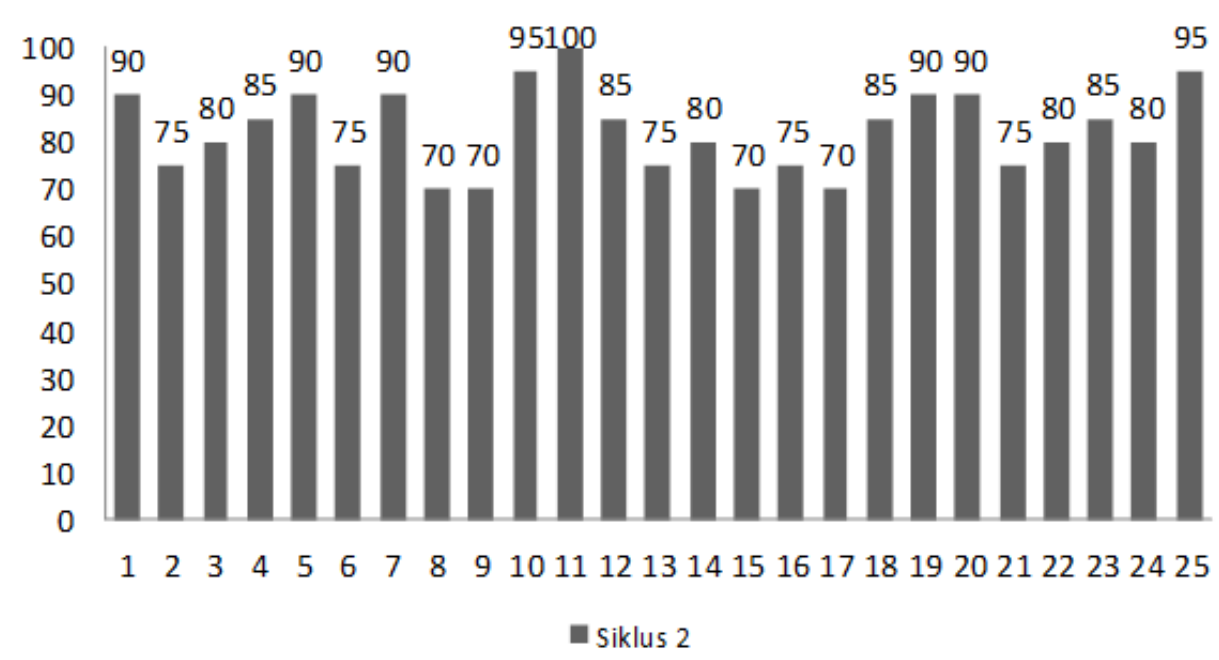

\section{Gambar 3 Perolehan Nilai Peserta Didik Saat Siklus 2}

Pada hasil siklus 1 bisa disimpulkan bahwa KKM kelas keseluruhan telah melewati nilai KKM yang ditetapkan sebesar 75, yaitu dengan nilai rata-rata kelas mencapai angka 76,4. Namun dengan persentase tingkat ketuntasan yang mencapai 56\% dari jumlah keseluruhan peserta didik, dapat disimpulkan bahwa masih banyak peserta didik yang belum mampu mencapai batas KKM yang ditetapkan, sejumlah 11 peserta didik dengan persentase $44 \%$ boleh dibilang masih terlalu tinggi jumlah peserta didik yang belum tuntas belajar materi passing bawah bolavoli. Oleh karena itu, peneliti memutuskan untuk melanjutkan penggunaan media modifikasi permainan 3 on 3 untuk materi passing bawah ke siklus 2. Hasil pelaksanaan siklus 2 terjadi peningkatan nilai rata-rata kelas yang mencapai angka 82,2, serta persentase tingkat ketuntasan mencapai angka 86\%, dengan rincian 21 peserta didik mampu mencapai batas KKM (Tabel 2). Dari hasil ketiga siklus yang sudah dipaparkan diatas, bisa ditarik kesimpulan jika penggunaan modfikasi permainan 3 on 3 untuk materi passing bawah bolavoli bisa dikatakan berhasil, hal ini merujuk dari pesentase tingkat ketuntasan pada siklus 3 yang mencapai besaran angka $86 \%$ tingkat ketuntasan. 
Tabel 2 Rekapitulasi Hasil Prasiklus, Siklus1, Dan Siklus 2

\begin{tabular}{|c|c|c|c|c|}
\hline Kegiatan & $\begin{array}{l}\text { Nilai Rata- } \\
\text { Rata Kelas }\end{array}$ & Kriteria & $\begin{array}{c}\text { Jumlah } \\
\text { Peserta } \\
\text { Didik }\end{array}$ & $\begin{array}{c}\text { Persentase } \\
\text { Tingkat } \\
\text { Ketuntasan }\end{array}$ \\
\hline Pra-Siklus & 68.6 & $\begin{array}{c}\text { Tuntas } \\
\text { Belum Tuntas }\end{array}$ & $\begin{array}{c}9 \\
16\end{array}$ & $36 \%$ \\
\hline Siklus 1 & 76.4 & $\begin{array}{c}\text { Tuntas } \\
\text { Belum Tuntas }\end{array}$ & $\begin{array}{l}14 \\
11\end{array}$ & $56 \%$ \\
\hline Siklus 2 & 82.2 & $\begin{array}{c}\text { Tuntas } \\
\text { Belum Tuntas }\end{array}$ & $\begin{array}{c}21 \\
4\end{array}$ & $84 \%$ \\
\hline
\end{tabular}

Berdasarkan hasil pada ketiga siklus diatas menunjukan bahwa dengan pengemasan materi pembelajaran yang dimodifikasi, berdampak pada peserta didik yang menyukai pembelajaran yang berorientasi pada permainan serta mampu memberikan perubahan yang signifikan pada peningkat-an keterampilan gerak peserta didik. Hal ini diakibatkan karena pada masa sekarang ini sebagian besar guru masih menggunakan pola pembelajaran yang kurang bisa menarik minat siswa untuk berartisipasi dalam pembelajaran. Dimana hanya dengan memberikan materi dengan metode yang terlalu monoton, tidak memberi inovasi dalam proses pembelajaran. Melihat keadaan seperti ini membuat materi permainan bolavoli tidak berjalan dengan baik dimana tidak semua peserta didik sudah memiliki kemampuan teknik dasar yang baik. Hasil penelitian ini diperkuat dengan apa yang dilakukan oleh Bagus Prastiyo Pambudi bahwa hasil passing bawah peserta didik meningkat setelah diterapkannya metode permainan (Pambudi, 2015: vii). Begitu juga dengan hasil penelitian Yusmar yang menunjukkan bahwa peningkatan keterampilan teknik dasar permainan bolavoli dapat ditingkatkan melalui modifikasi permainan (Yusmar, 2017).

Pembelajaran yang dikemas dengan metode per-mainan ini mampu memberikan kesempatan bagi peserta didik mengenali dirinya serta seberapa jauh penguasaan teknik dasar dan memberikan peluang untuk memperbaiki memiliki teknik dasar yang baik. Dengan memberikan metode permainan yang dimodifikasi, memberikan kesempatan peserta didik dapat berkembang sesuai dengan tahap-tahap kemampuannya, dengan begitu, akan memberikan kontribusi yang positif juga pada perolehan nilai akhir. Hal ini disebabkan karena keterampilan teknik dasar 
mempunyai ketentuan tertentu agar mampu melakukan keterampilan secara baik. Pencapaian suatu keterampilan dipengaruhi oleh banyak faktor, yaitu: (1) faktor proses belajar mengajar, (2) faktor pribadi, dan (3) faktor situasional/lingkungan (Amung Ma'mun dan Yudha, 2000). Pembelajaran yang menyenangkan serta kerjasama yang baik akan merubah situasi pembelajaran yang membosankan kearah yang lebih menyenangkan sehingga peserta didik bertambah minat serta motivasinya dalam pembelajaran. Belajar merupakan proses mengubah peserta didik dari tingkat kemampuan rendah kepada tingkat kemampuan yang lebih baik. Sehingga peningkatan minat belajar peserta didik memiliki kontribusi yang besar dalam keberhasilan belajar (Subekti et al., 2018: 162). Menarik minat belajar semudah hanya memberikan penguatan pada peserta didik saja, akan tetapi dengan mengemas pembelajaran sedemikian rupa untuk memfasilitasi peserta didik dalam bergerak bebas yang terarah (Rithaudin dan Hartati, 2016: 52).

\section{SIMPULAN}

Berdasarkan hasil penelitian yang sudah dilaksanakan maka penggunaan media modifikasi permainan 3 on 3 dalam pembelajaran bolavoli materi passing bawah sanggup memberikan peningkatan pada hasil belajar peserta didik, dengan capaian tingkat ketuntasan yang tinggi. Hasil penelitian ini juga diharapkan bisa membantu pengajar mata pelajaran PJOK untuk bisa berinovasi lebih demi meningkatkan hasil belajar peserta didik dengan berbagai macam modifikasi pembelajaran untuk materi pembelajaran yang lain. Untuk peneliti yang lain diharapkan juga mampu melakukan penelitian lebih lanjut dengan menggunakan materi diluar pembelajaran bolavoli.

\section{DAFTAR PUSTAKA}

Arifin, S. (2017). Internalisasi nilai sportivitas melalui pembelajaran pendidikan jasmani di sekolah dasar. Jurnal Sosioreligi, 20-29, (Online), (http://ejournal.upi.edu/index.php/SosioReligi/article/view/8834/5476, diakses 15 September 2019).

Aussie (1996). Modified sport aquality junior sport approach. Belconen: ACT Australian Sport Commision.

Bahagia, Y. (2014). Media dan alat pembelajaran penjas. (Online), 
(http://file.upi.edu/Direktori/FPOK/JUR._PEND._OLAHRAGA/19490316 1972111YOYO_BAHAGIA/(PP)_MEDIA_DAN_ALAT_PEMBELAJAR AN_PENJAS.pdf, diakses 7 Agustus 2019).

Depdiknas. (1999). Petunjuk tes keterampilan bola voli usia 15-17 tahun. Jakarta: Pusat Kesegaran Jasmani dan Rekreasi.

Depdiknas. (2003). Sistem pendidikan nasional. Departemen Pendidikan Nasional. Jakarta.

Fajri, M. (2019). Pemanfaatan modifikasi media pembelajaran bawah dalam permainan bola voli pada siswa kelas V MI Darul Mukminin. Genta Mulia, $\quad X(1), \quad 65-83 . \quad$ (Online), (http://ejournal.stkipbbm.ac.id/index.php/gm/article/view/247/233).

Furqon, H., M. (2010). Guru sejati: membangun insan berkarakter kuat dan cerdas. Surakarta: Yuma Pustaka.

Ginanjar, A., Suherman, A., Juliantine, T., \& Hidayat, Y. (2019). Sports orientation during learning team or individual sports using a sport education model. Cakrawala Pendidikan, 38(2), 377-386. (Online), (https://doi.org/10.21831/cp.v38i2.24021).

Hanansyah, A., \& Ginanjar, A. (2019). Upaya peningkatan hasil belajar bola basket menggunakan model pembelajaran group investigation improvement. JUARA: Jurnal Olahraga, 4(2), 90-98. (Online), (https://doi.org/https://doi.org/10.33222/juara.v4i2.543).

Indriyani, D. (2011). Peningkatan hasil belajar passing bawah pada bola voli dengan menggunakan permainan " 3 on 3 " pada siswa kelas VII SMP Negeri 1 Sukoharjo Wonosobo tahun pelajaran 2010 / 2011 (Universitas Negeri Semarang)._(Online), (http://lib.unnes.ac.id/10159/1/10112.pdf).

Lutan, R. (1988). Belajar keterampilan motorik: pengantar teori dan metode. Jakarta: Depdikbud.

Muslich, M. (2009). Melaksanakan PTK itu mudah. Jakarta: PT Bumi Aksara.

Ma'mun, Amung, dan Yudha. (2000). Perkembangan gerak dan belajar gerak. Jakarta: Departemen Pendidikan.

Pambudi, B. P. (2015). Meningkatkan keterampilan passing bawah bolavoli menggunakan permainan 4 on 4 untuk siswa kelas XI SMA Negeri 1 Kota Mungkid Kabupaten Magelang (Universitas Negeri Yogyakarta). (Online), (http://eprints.uny.ac.id/26418/1/Skripsi Bagus Prastiyo Pambudi.pdf).

Rithaudin, A., \& Hartati, B. S. (2016). Upaya meningkatkan pembelajaran passing bawah permainan bola voli dengan permainan glagahombo i tempel Sleman Yogyakarta. Jurnal pendidikan jasmani indonesia, 12(1), 51-57. (Online), (https://journal.uny.ac.id/index.php/jpji/article/view/10216/7937).

Saputra, I. (2015). Modifikasi media pembelajaran pendidikan jasmani sekolah dasar. Jurnal ilmu keolahragaan, 14(2), 35-41. (Online), (https://doi.org/https://doi.org/10.24114/jik.v14i2.6112).

Subekti, T. B. A., Hanief, Y. N., \& Mashuri, H. (2018). Meningkatkan hasil belajar passing bawah bolavoli melalui permainan 3 on 3 pada siswa sekolah dasar. Jurnal pendidikan jasmani dan olahraga, 3(2), 161-166. (Online), (https://doi.org/10.17509/jpjo.v3i2.12414). 
p-ISSN: 2089-2829

e-ISSN: 2407-1528

http://journal.ikippgriptk.ac.id/index.php/olahraga

DOI: 10.31571/jpo.v9i1.1333
Jurnal Pendidikan Olahraga

Vol.9, No.1 Juni 2020

hal 1-14

Yusmar, A. (2017). Upaya peningkatan teknik permainan bola voli melalui modifikasi permainan siswa kelas X SMA Negeri 2 Kampar. Jurnal pajar (pendidikan dan pengajaran), 1(1), 143. (Online), (https://doi.org/10.33578/pjr.v1i1.4381)

Ngasmain dan Soepartono. (1997). Modifikasi olahraga dan model pembelajarannya sebagai strategi pembinaan olahraga usia dini bernuansa pendidikan. Makalah disajikan pada konferensi nasional pendidikan jasmani dan olahraga. Bandung, 22-23 September. 